\title{
ON THE "SEIDENFADEN COLLECTION" AND THE MULTIPLE ROLES BOTANICAL GARDENS CAN PLAY IN ORCHID CONSERVATION
}

\author{
Henrik Æ. Pedersen ${ }^{1,3}$, Jens I. Find ${ }^{2, \dagger}$, Gitte Petersen ${ }^{1} \&$ Ole Seberg $^{1}$ \\ ${ }^{1}$ Natural History Museum of Denmark, University of Copenhagen, Øster Voldgade 5-7, \\ DK-1353 Copenhagen K, Denmark \\ ${ }^{2}$ Department of Geosciences and Natural Resource Management, University of Copenhagen, \\ Rolighedsvej 23, DK-1958 Frederiksberg C, Denmark \\ ${ }^{3}$ Author for correspondence: henrikp@snm.ku.dk \\ ${ }^{\dagger}$ Deceased $2^{\text {nd }}$ December 2016
}

\begin{abstract}
Using the "Seidenfaden collection" in Copenhagen as an example, we address the common view that botanical garden collections of orchids are important for conservation. Seidenfaden collected live orchids all over Thailand from 1957 to 1983 and created a traditional collection for taxonomic research, characterized by high taxonomic diversity and low intraspecific variation. Following an extended period of partial neglect, we managed to set up a five-year project aimed at expanding the collection with a continued focus on taxonomic diversity, but widening the geographic scope to tropical Asia. Since its establishment, the collection has contributed significantly to ex situ conservation and to research-based development of powerful tools for improving in situ conservation-related decisions and priorities. The collection has been, and still is, an important basis for taxonomic and floristic research which has enabled treatment of the Orchidaceae in the Thai red-list. However, the primary focus of our project has shifted to micro-propagation, DNA-barcoding and phylogenetic analysis. The close link between collection-based research and conservation is remarkable and probably applicable to plant collections in botanical gardens in general. Thus, if the collections are managed and used properly, they have great potential for contributing to conservation in many different ways.
\end{abstract}

KEY WORDS: DNA barcoding, gene banks, Orchidaceae, phylogenetics, public education, red-lists

According to the GardenSearch database (www. bgci/garden_search.php; accessed 30 January 2018) more than 3400 botanical gardens currently exist, distributed among c. 150 countries. Clearly, the vast majority of botanical gardens grow a certain number of orchid species, a significant proportion have collection sections entirely devoted to orchids, and some of the special orchid collections are more than century-old - for example those in Kew (Stewart 1992), Leiden (Schuiteman \& de Vogel 1999) and Copenhagen (Sterll 2002). This is no coincidence, as botanical garden collections of orchids are indispensable for research (Schuiteman \& de Vogel 1999). During expeditions in the wet tropics, more than $80 \%$ of the orchid species are found without flowers, but if live plants are taken into cultivation, they can be identified and important parts can be preserved when they bloom. Besides, living collections offer excellent opportunities for experimental studies of biology. For more than a century, these obvious advantages have underlain the establishment of orchid collections in botanical gardens. Consequently, the vast majority of such collections contain high taxonomic diversity, but limited intraspecific genetic diversity.

Gunnar Seidenfaden, Danish pioneering explorer of the Thai orchid flora (Friis 2002, Pedersen, Watthana \& Srimuang 2009, Rasmussen 2010), recognized the scientific potential and necessity of living orchid collections already in the mid-1950s, when he was appointed Denmark's first ambassador to Thailand. At the Royal Forest Department in Bangkok he met the young Thai botanist Tem Smitinand, and they soon started a long-lasting collaboration collecting and studying Thai orchids. Initially, their accessions were cultivated in the embassy compound, but they were transferred to the Botanical Garden, University 


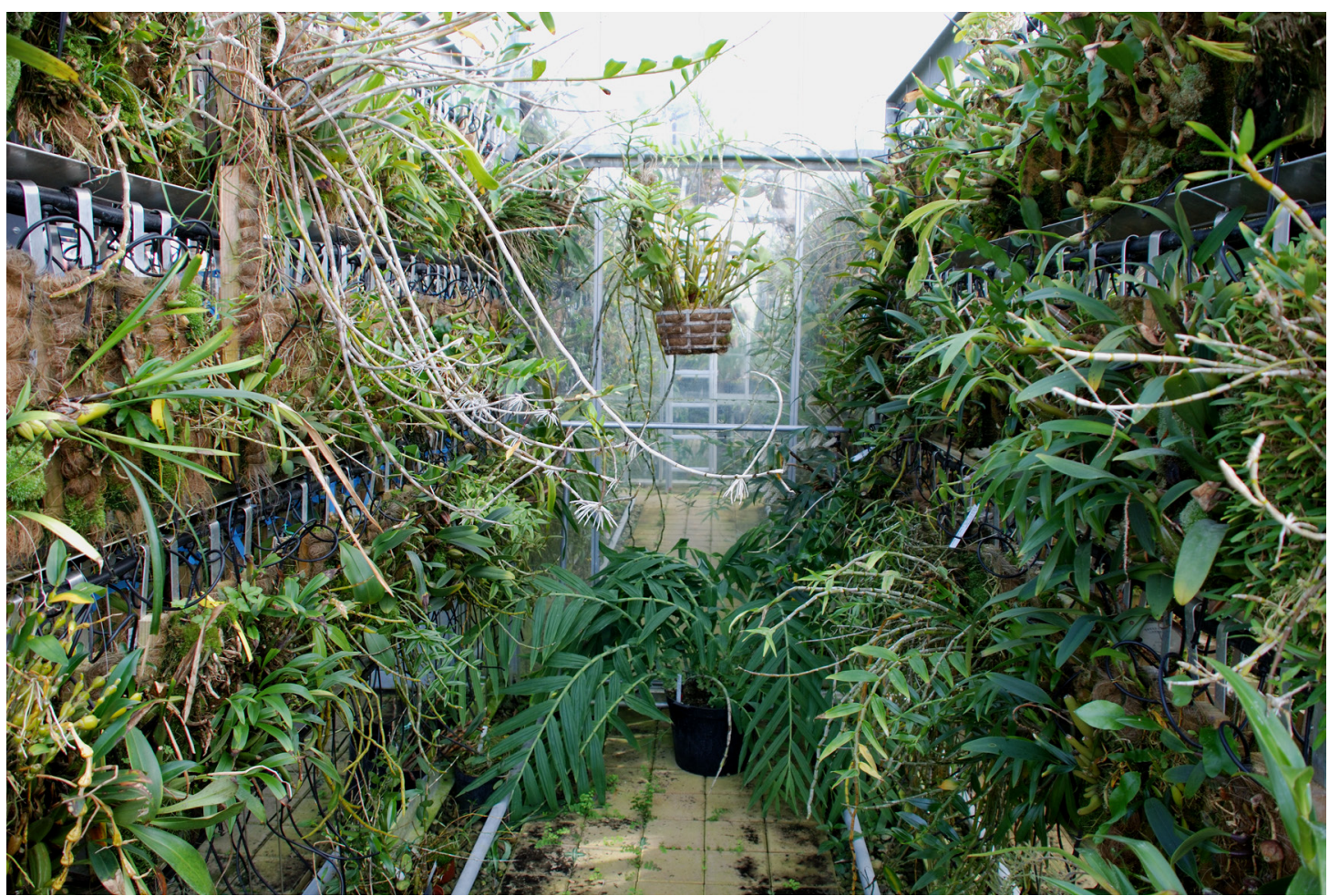

FIgURE 1. The Seidenfaden collection anno 2014 - accommodated in a modern greenhouse donated by the Augustinus Foundation in 2000. Photo by H. Æ. Pedersen.

of Copenhagen, around 1959 when Seidenfaden was posted to Moscow as Danish ambassador to the Soviet Union. Upon his return to Denmark in 1961, he was able to resume expedition activities during recurrent visits to Thailand. Consequently, the living collection kept growing until Seidenfaden's last expedition in 1983.

At this time, the collection in Copenhagen was larger than any other collection of Thai orchids, and five years later it still had about 3000 individual plants (Sterll \& Rasmussen 1988); regrettably, it is unclear how many species were represented. Due to unfortunate circumstances, the collection was not properly maintained for several years from c. 1970 onwards, and periodical lack of a specialist orchid gardener to look after the plants added to the problems. An annual loss of c. $5 \%$ of the individual plants is not unusual even in the best managed orchid collections; but the mortality rate in the Seidenfaden collection was significantly higher in the most critical periods, and quite a number of species were lost completely.

In August 2000, the orchid collection was moved to a state-of-the-art greenhouse donated by the
Augustinus Foundation (Pedersen 2004) (Fig. 1). A few years later, a gardener with special interest in orchid cultivation was transferred to the collection, and the automated shading and watering facilities were optimized, making the remaining plants (c. 750 accessions representing c. 240 species) gradually recover. Besides, a tissue culture laboratory and a DNA laboratory that became available to the Botanical Garden offered interesting new possibilities for cultivation and research based on the collection. To further strengthen the living collection and to utilize the new technical opportunities, we conducted a fiveyear combined research and conservation project: "Seidenfaden's Orchids - from Conventional Study Collection to Modern Research Facility and Gene Bank" (March 2012-February 2017).

Botanical garden collections of orchids are often emphasized as being of importance for conservation (e.g. Koopowitz 2001, Schuiteman \& de Vogel 1999, Swarts \& Dixon 2009, Tasker 1989), and the need for ex situ conservation increases parallel to increasing threats (e.g. habitat destruction, over-collection and 
global warming; Koopowitz 2013, Seaton, Hu, Perner \& Pritchard 2010, Wyse Jackson \& Sutherland 2013). However, the limited intraspecific genetic variation in traditional collections may clearly represent a serious limitation of the extent to which propagated plants from these can potentially be used for genetically sustainable recovery programmes in the wild. If this is the case, it raises the question whether traditional collections are useful at all in recovery contexts? A few other questions also seem relevant: Is plant material properly shared with sister collections to secure longterm ex situ conservation? Do gene banks of seeds and tissue cultures have a role to play? Do traditional collections contribute to conservation in any other way? In this paper, we will address these questions, using the "Seidenfaden collection" in Copenhagen as an example.

\section{Development and characteristics of the Seidenfaden}

collection. Seidenfaden aimed at establishing a living study collection for morphology-based taxonomic and floristic research. This strategy is clearly reflected in the composition of the collection which is characterized primarily by high diversity at genus and species level and secondarily by many species being represented by a few clones of different provenance. In other words, it was established as a traditional botanical garden collection, though with a narrow geographic focus. Besides providing an ideal resource for taxonomic studies, the high diversity at genus and species level made the collection very well suited for comparative morphological, ontogenetic and biological studies, including experimental hybridization (e.g. Andersen, Johansen, Lund, Rasmussen, Rasmussen \& Sørensen 1988, Johansen 1990, 1993, Rasmussen 1982). Throughout Seidenfaden's era, accession was very strongly focused on properly documented, wildcollected material from Thailand. However, the enforcement of national and international regulations, partly as a consequence of CITES (www.cites.org) and the Convention on Biological Diversity (www.cbd.int), made it increasingly difficult to add to the collection in this manner.

In our recent project, Seidenfaden's original collection, supplemented with the relatively few other tropical Asian orchid species in the Botanical Garden, was further developed with a continued focus on maximizing primarily its taxonomic diversity and secondarily the number of provenances of each species. However, right from the start we had to realize that it would be impossible to obtain additional wild-collected adult plants from Thailand. Instead, we decided to concentrate our effort on two other options: (1) donations of plant material from other European botanical gardens and, in special cases, from private orchid growers; (2) donations of seeds from Queen Sirikit Botanic Garden (QSBG) for asymbiotic germination and subsequent transfer of juvenile plants to the greenhouse. Wildcollected Thai orchids are rare in all other European botanical gardens, and whereas amateur collections often contain many orchid species known to occur in Thailand the plants are usually of unknown provenance. Partly as a consequence of our limited possibilities to obtain new plants of Thai provenance, we broadened the scope of the collection to represent tropical Asian orchids in general. However, for scientific reasons we particularly had in view to increase the holdings of (1) Thai orchids, (2) the genus Dendrochilum Blume, which is exceptionally rich in narrow endemics, and (3) endemic taxa in general. The majority of new accessions were of well-documented provenance, but occasional exceptions were accepted for material of rare endemic species. During the project, we received 244 new accessions (228 adult plants, 16 seed samples) mainly from Hortus Botanicus (Leiden), Royal Botanic Gardens (Kew), QSBG (Chiang Mai), Malcolm Perry (Bristol) and Richard C. Warren (Barnard Castle). Of the 16 seed samples, only seven germinated sufficiently well to result in new adult plants for the greenhouse. In total, new plants for the greenhouse represented c. 150 species, most of which did not already exist in the collection.

In conclusion, the living collection of tropical Asian orchids in Copenhagen remains primarily targeted on taxonomic diversity. This makes the collection very well suited for systematic and a wide range of biological studies. The long history of the collection makes it probable that it contains genotypes from wild populations that are now extinct.

From collections to red-listing. Largely by sampling his living collection, as the plants came into flower, Seidenfaden gradually built a comprehensive spirit collection. After his death in 2001 the spirit collection, 
consisting of more than 11,000 vials, was transferred to the Botanical Museum in Copenhagen (now part of the Natural History Museum of Denmark).

During his career as orchidologist, Seidenfaden conducted two complete revisions of the Thai orchid flora - the first in collaboration with Tem Smitinand (Seidenfaden \& Smitinand 1959-1965), the last on his own (Seidenfaden 1975-1980, 1982-1988). In both cases, the taxonomic and floristic research relied to a wide extent on examination of the spirit samples, combined with observations made in the living collection (Pedersen et al. 2009, Rasmussen 2010).

Exploration of the Thai orchid flora (and of the Thai flora in general) started late, implying that the knowledge of species diversity and distribution patterns remained fragmentary until modern time. For example, Williams (1904-1905) included just c. 100 orchid species in his "Liste des Plantes Connues du Siam". Arthur F. G. Kerr, who lived in Thailand from 1902 to 1932 , made more than 2000 orchid collections (Parnell et al. 2015), but published very little on the orchid flora (Jacobs 1962). Indeed, the book of Seidenfaden \& Smitinand (1959-1965) marked the beginning of serious exploration of the Thai orchid flora (documenting 771 identified and 87 unidentified species), and Seidenfaden's later revision increased the number of known species to c. 1200.

The highly improved knowledge of the overall diversity and composition of the Thai orchid flora and the identity, distribution and frequency of individual species - mainly achieved through Seidenfaden's monumental contribution - created the necessary basis for a reasonably complete and sound treatment of the Orchidaceae in the first national Thai red-list (Santisuk, Chayamarit, Pooma \& Suddee 2006).

By definition, taxonomic and distributional surveys of national floras always represent a point in time and can never be perfect; species disperse, populations disappear, field exploration reveals previously overlooked occurrences, and new species are recognized while others are rejected as being taxonomically unwarranted. Consequently, continued taxonomic and floristic research is needed for improving the red-lists and keeping them up-to-date. A third complete revision of the Thai orchid flora is now being conducted as part of the Flora of Thailand project; two of six planned instalments have already been published (Pedersen, Kurzweil, Suddee \& Cribb 2011, Pedersen et al. 2014). A comparison of the Flora of Thailand account on the Orchidoideae (Pedersen et al. 2011) with the two previous revisions of this subfamily has amply demonstrated the usefulness of revising the Thai orchid flora repeatedly (Pedersen 2013). The three revisions done during half a century exhibited a progressive increase in the net number of taxa accepted, and the total number of changes was even higher, as additions and exclusions partly neutralized each other.

Although the current orchid studies for Flora of Thailand depend less on the living collection in Copenhagen for solving taxonomic problems, the live plants still provide an important resource for checking and completing species descriptions - especially concerning colours, leaf texture, flowering mode and floral scent. Surprisingly, it also still happens that new national records for Thailand are revealed among Seidenfaden's old plants; the latest examples are Liparis vestita Rchb.f. (Tetsana, Pedersn \& Sridith 2013) and Coelogyne lawrenceana Rolfe (Pedersen et al. 2014) (Fig. 2).

DNA barcoding. The concept of DNA barcoding as identification tool was formalized around 2000 (e.g. Hebert, Cywinska, Ball \& deWard 2003), and rapid development of formal international collaboration (covering all organismal kingdoms) resulted in establishment of the Consortium for the Barcode of Life (CBOL) in May 2004. However, using only one barcode for all life was soon shown to be unrealistic. As far as land plants are concerned, a core-barcode consisting of portions of two coding chloroplast regions, matK and $r b c L$, was recommended (CBOL Plant Working Group 2009). Subsequent studies targeted on taxonomically or geographically defined groups of orchids have indicated that other molecular markers offer better resolution (e.g. Kim, Oh, Bhandari, Kim \& Park 2014, Xiang, Hu \& Jin 2011), but these studies have ignored the advantages of a broadly applied consensus barcode.

For a few decades, the living orchid collection in Copenhagen has served as a useful source of tissue samples for DNA analysis. Until recently, the sampling was very much ad hoc and usually prompted by requests from foreign researchers who needed additional 

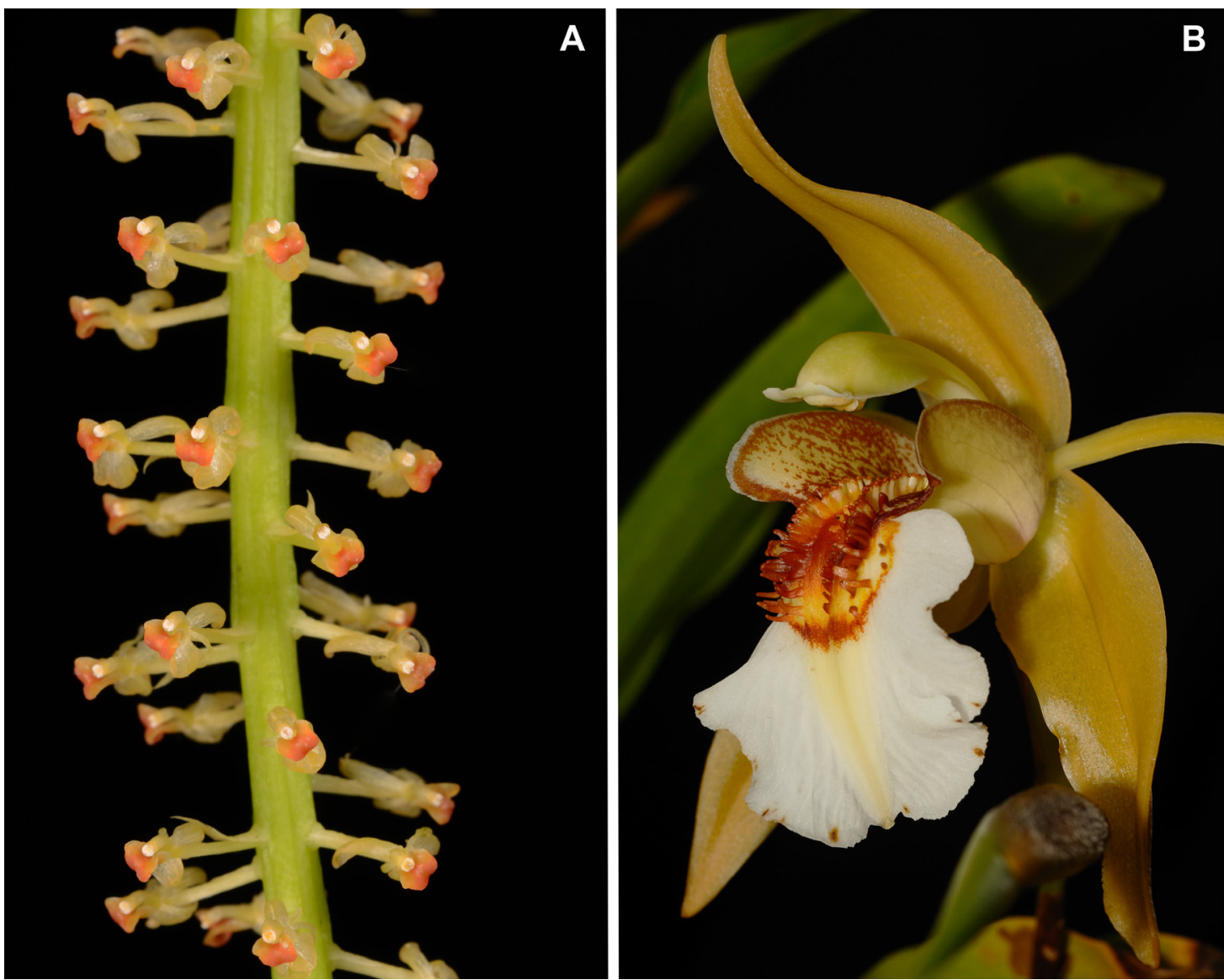

FIGURE 2. The two latest examples of new national records for Thailand revealed in Seidenfaden's living collection; both species are obvious candidates for inclusion in the next edition of the national Thai red-list. A. Liparis vestita Rchb.f. - in Thailand only known from Amphoe Rong Kwang in Phrae and from two sites in Khao Yai National Park (Nakhon Nayok, Prachin Buri). B. Coelogyne lawrenceana Rolfe - in Thailand only known through a single plant collected on Doi Inthanon (Chiang Mai) in 1978. Photos by H. Æ. Pedersen.

samples for their phylogenetic studies. However, sampling was standardized considerably in our recent project, as we decided to DNA barcode as many of the identified species as funding would allow. For this purpose, we adopted the officially recommended core-barcode for land plants, supplemented by ITS. We sampled a total of 131 species from the collection, and the prepared barcodes will be made publicly available as soon as possible.

Establishment of a vouchered reference collection of barcode data, such as the Barcode of Life Data Systems (BOLD), is a prerequisite for consistent applications of DNA barcoding. Admittedly, the potential and resolution power of the new technique have been questioned by a number of authors (e.g.
Seberg \& Petersen 2009, Taylor \& Harris 2012), but if used with care, DNA barcoding is a cheap, quick and sufficiently reliable technique for many purposes. In a conservation context, as reviewed by Krishna Krishnamurthy \& Francis (2012), DNA barcodes can provide information for the use of different stakeholders. For example, they may offer quicker species identification, help to pinpoint groups of species complexes in need of in-depth studies, and may empower policy makers to take the most appropriate conservation measures.

We primarily envisage two useful purposes for the future use of our barcode data: (1) as a tool enabling customs authorities to identify even nonflowering orchids and thus reveal their CITES status 
and whether the claimed geographic origin of the plants is plausible; (2) as a tool for virtually nondestructive inventories and comparisons of species diversity of orchids in selected nature areas, thus facilitating quick and qualified conservation priorities to be made without any need to observe the plants in bloom. Both options would require our data to be used in conjunction with additional reference data provided by other researchers, but building a reference library of barcodes is the necessary first step towards more general use.

Phylogenetic studies. Whereas the core-barcode itself is mainly suited for species identification, DNA extractions offer a rich and readily accessible source of material for additional DNA sequencing that can be used for in-depth phylogenetic studies of selected taxa or in genomics. This opportunity was also utilized in our recent project. Thus, in collaboration with colleagues abroad (and partly based on comprehensive sampling in the Copenhagen collection), we made a phylogenetic reconstruction of subtribe Eriinae $(\mathrm{Ng}$ et al. 2018), and a similar study of the large genus Dendrochilum is underway (Pedersen et al., in prep.).

Species diversity is by far the most commonly used measure of biodiversity, but Vane-Wright, Humphries \& Williams (1991) proposed "phylogenetic diversity", a measure based on evolutionary relationships between species, as an additional parameter for setting conservation priorities (see also Mace, Gittleman \& Purvis 2003). Although the relevance and applicability of this measure is in need of further clarification (Winter, Devictor \& Schweiger 2012), phylogenies offer an interesting alternative biodiversity measure that is largely resistant to taxonomic inflation (e.g. Pillon, Fay, Shipunov \& Chase 2006).

Gene banking and micro-propagation. Notwithstanding the value of traditional botanical garden collections, such collections can only have a few individuals of each species (e.g. Justice 2016). Consequently, there is a pressing need for supplementary, less space-demanding ex situ conservation facilities such as seed banks and in vitro gene banks (e.g. Ramsay \& Dixon 2003, Seaton et al. 2010, Seaton \& Pritchard 2003).

In vitro recalcitrance (the inability of plant cells and tissue to respond to manipulations in vitro) can be a major limiting factor for conservation initiatives (Sarasan 2011), and mature seeds of many orchid species are recalcitrant (e.g. Butcher \& Marlow 1989). This problem can be addressed either by developing techniques to break the recalcitrance or by using immature seeds. The latter option usually implies successful asymbiotic germination, but immature seeds in a suitable stage are only available in a short time-window, as efficient and broadly applicable preservation techniques have not yet been developed (Sarasan 2011). Even the viability of mature seeds stored at cool or temperate conditions deteriorates gradually over time, but techniques for cryopreservation in nitrogen vapour $\left(-156^{\circ} \mathrm{C}\right)$ are within reach for mature orchid seeds and have already been implemented for a number of species (e.g. Hicks 2002, Thammasiri 2013). Cryopreservation can also be applied to tissue cultures to circumvent the potential problem of somaclonal variation.

Plant tissue culture under sterile conditions provides a technique for clonal propagation of plants from small amounts of vegetative tissue such as stem and shoot meristems and leaf fragments (e.g. Stewart 1989). In cases of self-incompatibility combined with lack of suitable genotypes for cross-pollination, in cases of strongly recalcitrant seeds etc., clonal tissue culture can be the only choice for micro-propagation. This technique normally increases the number of plants more quickly than could be done through division of adult plants.

Based on the Copenhagen collection of tropical Asian orchids, supplemented by seeds received from QSBG, we made a research-based effort at germinating orchid seeds asymbiotically (Fig. 3), and we used the resulting tissue cultures to establish an in vitro gene bank. We particularly aimed at developing techniques for breaking the recalcitrance of mature seeds, although immature seeds were occasionally applied. We also developed techniques for successful clonal propagation of species of Bulbophyllum Thouars and Dendrobium Sw. (Fig. 4). Altogether, we established an in vitro gene bank comprising cultures of 26 species (Table 1) - including seven that are endemic to Thailand or the Philippines and 16 that are included in the latest edition of the national Thai red-list (Chamchumroon, Suphuntee, Tetsana, Poopath \& Tanikkool 2017). Gene 


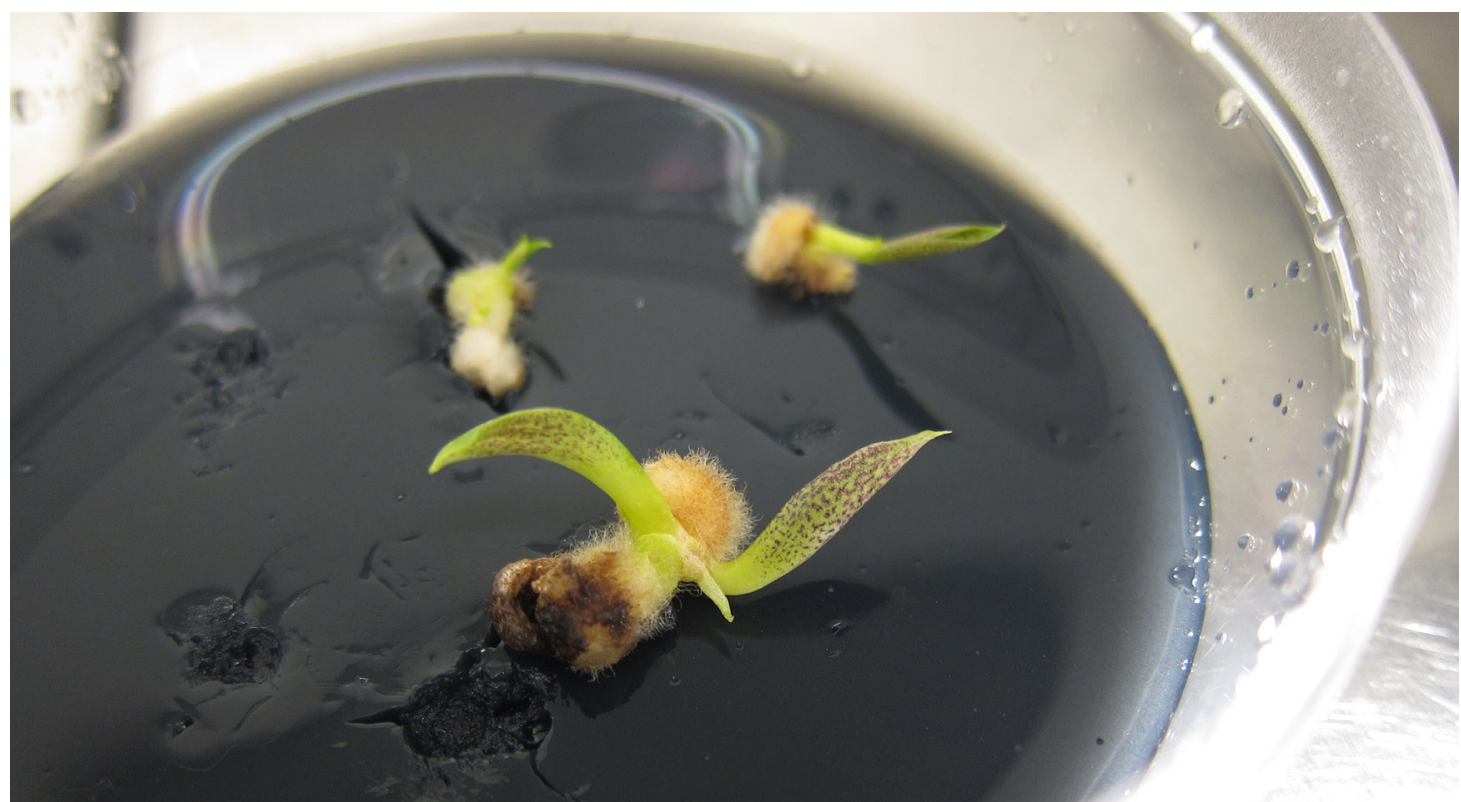

FIGURE 3. Plantlets of Sirindhornia pulchella H. A. Pedersen \& Indham. grown from asymbiotically germinated seeds. This species is considered endemic to Doi Chiang Dao in the northern Thai province of Chiang Mai, and it is classified as endangered $(\mathrm{EN})$ in the national Thai red-list. Photo by J. I. Find.

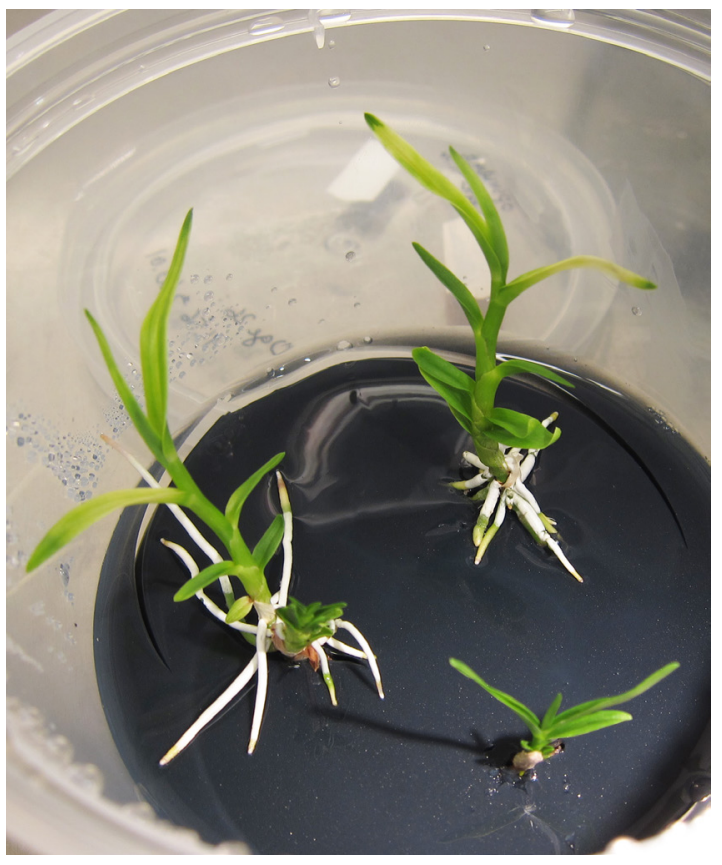

FIgURE 4. Plantlets of the rare Dendrobium chrysanthum Lindl. grown asymbiotically from vegetative explants. This was one of the first nationally red-listed species for which we were able to offer our Thai counterparts mass-propagated material for preparation of a recovery project in the wild. Photo by J. I. Find. banking through cryopreservation was not part of our project. However, we did use subsets of most seed samples for development of suitable cryo-techniques, and the established in vitro gene bank provides a solid basis for potentially using cryopreservation in the future.

Sharing of material. Ex situ collections ensure conservation of a high number of species - and often for a very long period when combined with in vitro techniques and cryopreservation. Still, the individual collections are vulnerable to local threats such as virus attacks, failing heating systems, shortage of (qualified) staff etc. Therefore, it is crucial that material of rare and narrowly endemic species is propagated and shared with other scientific collections to the widest possible extent allowed under international legislation. Though not impossible, one has to realize that the implementation of the Nagoya-protocol (www.cbd.int/ $\mathrm{abs} /$ ) is going to complicate such exchanges, at least for all material collected after October 12th, 2014.

For years, the orchid collection in Copenhagen has been involved in exchange of material with a number of botanical gardens in Europe; and a subset of the first asymbiotically propagated plants of Thai orchids was donated to QSBG in 2016 (Table 1). 
TABLE 1. Survey of the 26 orchid species that we established in the in vitro gene bank of the Botanical Garden in Copenhagen. For each species is indicated whether it is endemic to a single country, and for those occurring in Thailand the current national conservation status in that country is indicated according to Chamchumroon et al. (2017) (EN = endangered, $\mathrm{R}=$ rare, $\mathrm{VU}=$ vulnerable). Finally, it is indicated how many plantlets of each species we donated to QSBG in 2016.

\begin{tabular}{|c|c|c|c|}
\hline Species & Endemic? & $\begin{array}{l}\text { Status in } \\
\text { Thailand }\end{array}$ & $\begin{array}{l}\text { Plantlets } \\
\text { to QSBG }\end{array}$ \\
\hline Acriopsis liliifolia (J.Koenig) Seidenf. & - & - & - \\
\hline Bletilla foliosa (King \& Pantl.) Tang \& F.T.Wang & - & VU & - \\
\hline aBulbophyllum brevistylidium Seidenf. & Thailand & - & 55 \\
\hline Bulbophyllum nesiotes Seidenf. & Thailand & EN & 7 \\
\hline Bulbophyllum peninsulare Seidenf. & Thailand & VU & - \\
\hline Bulbophyllum propinquum Kraenzl. & - & VU & 3 \\
\hline Bulbophyllum smitinandii Seidenf. \& Thorut & - & VU & - \\
\hline Coelogyne lawrenceana Rolfe & - & - & - \\
\hline Dendrobium chrysanthum Wall. ex Lindl. & - & $\mathrm{R}$ & 75 \\
\hline Dendrobium devonianum Paxton & - & $\mathrm{R}$ & 78 \\
\hline Dendrobium friedericksianum Rchb.f. & - & VU & - \\
\hline Dendrobium jenkinsii Wall. ex Lindl. & - & $R$ & - \\
\hline Dendrobium sulcatum Lindl. & - & $\mathrm{R}$ & 6 \\
\hline Dendrobium wardianum R.Warner & - & $\mathrm{R}$ & 9 \\
\hline Dendrochilum diabloviride Cootes \& R.Boos & Philippines & $\mathrm{n} / \mathrm{a}$ & - \\
\hline Dendrochilum filiforme Lindl. & Philippines & $\mathrm{n} / \mathrm{a}$ & - \\
\hline Dendrochilum glumaceum Lindl. & - & $\mathrm{n} / \mathrm{a}$ & - \\
\hline Epipactis flava Seidenf. & - & EN & - \\
\hline Grammatophyllum speciosum Blume & - & VU & - \\
\hline Liparis sp. & $?$ & - & - \\
\hline Liparis viridiflora (Blume) Lindl. & - & - & - \\
\hline Odontochilus elwesii C.B.Clarke ex Hook.f. & - & - & - \\
\hline Odontochilus lanceolatus (Lindl.) Blume & - & - & - \\
\hline Sirindhornia mirabilis H.A.Pedersen \& Suksathan & Thailand & EN & - \\
\hline Sirindhornia pulchella H.A.Pedersen \& Indham. & Thailand & EN & - \\
\hline Trichoglottis triflora (Guillaumin) Garay \& Seidenf. & - & VU & - \\
\hline
\end{tabular}

${ }^{a}$ By some authors treated as synonym of the non-endemic Bulbophyllum longerepens Ridl.

Recovery programmes. The ultimate success of $e x$ situ conservation activities would be if propagated plants could be used for genetically sustainable recovery programmes in the wild - preferably integrated in ambitious ecological restoration projects (e.g. Hardwick et al. 2011, Miller, Lowry II, Aronson, Blackmore, Havens \& Maschinski 2016). It is frequently argued that for ex situ collections to be of use in such programmes, the plants must be of known wild origin and possess a genetic diversity representative of one or more wild populations (cf. Rae 2011).

While being well documented, the collection of orchids in Copenhagen does not fulfil the latter criterion - a deficiency shared with the vast majority of other scientific orchid collections. Although the great diversity of breeding systems and widely divergent levels of genetic diversity among individual orchid species (e.g. Phillips, Dixon \& Peakall 2012, Tremblay, Ackerman, Zimmerman \& Calvo 2005) should always be borne in mind, it is evident that, in most cases, propagated plants from collections will be inadequate for genetically sustainable recovery of natural populations. However, as stressed by Pence (2011), they can be used to test the suitability of 
habitats and microhabitats in preparation of recovery programmes. Such experiments should be performed following detailed autecological field studies of wild populations (e.g. Watthana \& Pedersen 2008), and also niche modelling and genetic screening of natural populations are useful tools. Due to the need for collecting comprehensive material for propagation purposes, recovery programmes normally have to be conducted on a national basis (e.g. Pedersen 2010). For detailed recommendations on plant reintroduction programmes in general, see Godefroid et al. (2011).

Among the material that we donated to QSBG in 2016, the plantlets of Dendrobium chrysanthum Lindl. (Fig. 4) and D. devonianum Paxton were so numerous that QSBG intends to use some of them for field experiments in preparation of reintroduction (or reinforcement) programmes.

Education and public outreach. Light, Kell \& Wyse Jackson (2003), Rae (2011) and Wyse Jackson \& Sutherland (2013) highlighted training, public outreach and schools education as some of the foremost roles botanical gardens and their collections could play in a conservation context. Furthermore, Williams, Jones, Gibbons \& Clubbe (2015) provided quantitative evidence suggesting that botanical gardens can indeed positively influence visitors' environmental attitudes.

Material from the recently expanded orchid collection in Copenhagen was used in the university course Plant-Animal Interactions in 2014 and 2015, and our project in its entirety was presented as case in the course International Nature Conservation in 2015. In connection with the donation of tissue cultures to QSBG in June 2016, we made a press release ("Rare orchids return to Thailand"), the content of which found its way to at least 25 media. The project and the collection were presented to a large and broad selection of public visitors in connection with the annual "Botanical Garden's Day" in Copenhagen during 2012-2015. In addition, we continuously updated the Botanical Garden's permanent guides on the progress of our project and thus enabled them to explain to the public why the collection is internationally important in a conservation context. The guides now provide qualified information on the orchid collection and its conservation-related importance during almost all the c. 80 guided tours of the Botanical Garden that are booked every year.

Conclusions and perspectives. Any sound conservation contribution rooted in a botanical garden collection rests on a base of good horticultural practice and succession of staff (securing long-term survival and propagation of the plants) as well as continuity of qualified scientific input (securing accurate identifications and a well thought-out accession policy). As outlined above, the Seidenfaden collection has contributed significantly to ex situ conservation and to research-based development of powerful tools for improving in situ conservation decisions and priorities. Its contributions have been continuous and diverse, and have changed over time. Its original role as a collection for taxonomic and floristic studies could be fulfilled with hardly any other means than the collection itself, vials with spirit and a low-power binocular microscope. In contrast, most of the new initiatives - such as DNA barcoding, DNAbased phylogenetic studies, in vitro propagation etc. - mainly utilize the collection as a source of material for laboratory use. Periods of intensive research have implied increased external funding and/or increased international collaboration, both of which have boosted the conservation-related contributions.

We find it obvious to assume that the overall importance and dynamics exhibited by the Seidenfaden collection represent the role of active botanical garden collections in general: increased scientific research generates increased contributions to conservation. Thus, if the traditional collections of, e.g., live orchids are assigned scientific attention, they have great opportunities for contributing to conservation (see also Delmas, Larpin \& Haevermans 2011, Pedersen 2010, Swarts \& Dixon 2009). Some collection-based contributions are as conventional as making the collections themselves in the field, while others are much more high-tech. As time progresses, contributions from DNA barcoding (providing new identification and inventory tools), phylogenies (for improved conservation priorities), cryopreservation (for millennium-long ex situ conservation) and largescale micro-propagation (in preparation of recovery programmes) may all become important routine contributions. Living collections also have an important 
role for upcoming techniques that are nowhere near showing their full potential, like genomics.

All in all, botanical gardens offer more diverse contributions to conservation of orchids (and other species) than commonly recognized - see also Donaldson (2009). However, any potential contribution ultimately depends on access to scientifically wellcurated plant material and continuous qualified nursing of individual plants - conditions that require a targeted core budget and proper scientific management of the botanical garden concerned.
Acknowledgements. We are grateful to the Augustinus Foundation for financial support, and we cordially thank our international collaborators for sharing material and ideas. International collaboration has mainly been achieved via fruitful contacts with Santi Watthana (QSBG, Chiang Mai), André Schuiteman and Christopher Ryan (Royal Botanic Gardens, Kew), Rogier van Vugt, Gerda A. van Uffelen and Paul J. A. Kessler (Hortus Botanicus, Leiden), Malcolm Perry (Bristol) and Richard C. Warren (Barnard Castle). Finally, we are indebted to Jimmy Olsen, Charlotte Hansen, El Bihrmann and Lisbeth Hansen for their skilled efforts in the greenhouse and laboratories.

\section{LITERATURE CITED}

Andersen, T. F., Johansen, B., Lund, I., Rasmussen, F. N., Rasmussen, H. \& Sørensen, I. (1988). Vegetative architecture of Eria. Lindleyana, 3, 117-132.

Butcher, D. \& Marlow, S. A. (1989). Asymbiotic germination of epiphytic and terrestrial orchids. In: H. W. Pritchard (Ed.), Modern methods in orchid conservation: the role of physiology, ecology and management (pp. 31-38). Cambridge: Cambridge University Press.

CBOL Plant Working Group (2009). A DNA barcode for land plants. Proceedings of the National Academy of Sciences of the United States of America, 106, 12794-12797.

Chamchumroon, V., Suphuntee, N., Tetsana, N., Poopath, M. \& Tanikkool, S. (2017). Threatened plants in Thailand. Bangkok: Department of National Parks, Wildlife and Plant Conservation.

Delmas, M., Larpin, D. \& Haevermans, T. (2011). Rethinking the links between systematic studies and ex situ living collections as a contribution to the Global Strategy for Plant Conservation. Biodiversity and Conservation, 20, 287-294.

Donaldson, J. S. (2009). Botanic gardens science for conservation and global change. Trends in Plant Science, 14, 608-613. Friis, I. (2002). Gunnar Seidenfaden (1908-2001): Arctic explorer, ambassador and orchidologist. Taxon, 51, 405-411.

Godefroid, S., Piazza, C., Rossi, G., Buord, S., Stevens, A.-D., Aguraiuja, R., Cowell, C., Weekley, C. W., Vogg, G., Iriondo, J. M., Johnson, I., Dixon, B., Gordon, D., Magnanon, S., Valentin, B., Bjureke, K., Koopman, R., Vicens, M., Virevaire, M. \& Vanderborght, T. (2011). How successful are plant species introductions? Biological Conservation, 144: 672-682. Hardwick, K. A., Fiedler, P., Lee, L. C., Pavlik, B., Hobbs, R. J., Aronson, J., Bidartondo, M., Black, E., Coates, D., Daws, M. I., Dixon, K., Elliott, S., Ewing, K., Gann, G., Gibbons, D., Gratzfeld, J., Hamilton, M., Hardman, D., Harris, J., Holmes, P. M., Jones, M., Mabberley, D., MacKenzie, A., Magdalena, C., Marrs, R., Milliken, W., Mills, A., Lughadha, E. N., Ramsay, M., Smith, P., Taylor, N., Trivedi, C., Way, M., Whaley, O. \& Hopper, S. D. (2011). The role of botanic gardens in the science and practice of ecological restoration. Conservation Biology, 25, 265-275.

Hebert, P. D. N., Cywinska, A., Ball, S. L. \& deWard, J. R. (2003). Biological identifications through DNA barcodes. Proceedings of the Royal Society of London, Series B, 270, 313-321.

Hicks, A. J. (2002). The Orchid Seedbank Project. Orchid Review, 110, 210-211, 222.

Jacobs, M. (1962). Reliquiae Kerrianae. Blumea, 11, 427-493.

Johansen, B. (1990). Incompatibility in Dendrobium (Orchidaceae). Botanical Journal of the Linnean Society, 103, 165196.

Johansen, B. (1993). Distribution of intramembrane particles in the pollen tube plasma membrane of Dendrobium secundum (Orchidaceae). Lindleyana, 8, 9-14.

Justice, D. (2016). The role of botanical gardens in plant conservation. Acta Horticulturae, 1140, 127-130.

Kim, H. M., Oh, S.-H., Bhandari, G. S., Kim, C.-S. \& Park, C.-W. (2014). DNA barcoding of Orchidaceae in Korea. Molecular Ecology Resources, 14, 499-507.

Koopowitz, H. (2001). Orchids and their conservation. London: B. T. Batsford Ltd.

Koopowitz, H. (2013). Global change and its ramifications for orchid conservation. In: J. Elliott, H. F. Kurzweil, P. O’Byrne, K. W. Tan, A. S. van der Schans, S. M. Wong \& T. W. Yam (Eds.), Proceedings of the 20th World Orchid Conference, Singapore, 2011 (pp. 438-443). Singapore: National Parks Board \& Orchid Society of South East Asia.

Krishna Krishnamurthy, P. \& Francis, R. A. (2012). A critical review on the utility of DNA barcoding in biodiversity conservation. Biodiversity and Conservation, 21, 1901-1919. 
Light, M. H. S., Kell, S. P. \& Wyse Jackson, P. S. (2003). The role of education and training in orchid conservation: an overview and critique. In: K. W. Dixon, S. P. Kell, R. L. Barrett \& P. J. Cribb (Eds.), Orchid conservation (pp. 357-382). Kota Kinabalu: Natural History Publications (Borneo).

Mace, G. M., Gittleman, J. L. \& Purvis, A. (2003). Preserving the tree of life. Science, 300, 1707-1709.

Miller, J. S., Lowry II, P. P., Aronson, J., Blackmore, S., Havens, K. \& Maschinski, J. (2016). Conserving biodiversity through ecological restoration: the potential contributions of botanical gardens and arboreta. Candollea, 71, 91-98.

Ng, Y. P., Schuiteman, A., Pedersen, H. Æ., Petersen, G., Watthana, S., Seberg, O., Pridgeon, A. M., Cribb, P. J. \& Chase, M. W. (2018). Phylogenetics and systematics of Eria and related genera (Orchidaceae: Podochileae). Botanical Journal of the Linnean Society, 186, 179-201.

Parnell, J. A. N., Pilla, F., Simpson, D. A., van Welzen, P. C., Chayamarit, K., Chantaranothai, P., Boyce, P. C., Bygrave, P., Byrne, C., Chen, S., Couch, C., Curtis, T., Dransfield, S., Duyfjes, B. E. E., Eianthong, W., Esser, H. J., Grote, P. J., Hua, Z., Jebb, M. H. P., Kirkup, D. W., Ke Loc, P., Larsen, S. S., Macklin, J., Madern, A., Meade, C., Merklinger, F., Middleton, D. J., Moat, J., Muasya, A. M., Nakmuenwai, P., Pedersen, H. Æ., Pendry, C. A., Prajaksood, A., Pooma, R., Preusapan, K., Puglisi, C., Sathapattayanon, A., Sukkharak, P., Staples, G., Strijk, J., Suddee, S., Sungkaew, S., Tangjitman, K., Teerwatananon, A., Tovaranonte, J., Ung, T., Trias Blasi, A., de Willde, W. J. J. O., Wilkin, P. \& Yahara, T. (2015). A re-examination of the life and work of A. F. G. Kerr and of his colleagues and friends. Thai Forest Bulletin (Botany), 43, 111-131.

Pedersen, H. Æ. (2004). The Seidenfaden orchid collections in Copenhagen - their origin, arrangement and utilization. In: K. S. Manilal, \& C. Sathish Kumar (Eds.), Orchid memories: a tribute to Gunnar Seidenfaden (pp. 1-6). Calicut: Mentor Books \& Indian Association for Angiosperm Taxonomy (IAAT).

Pedersen, H. Æ. (2010). Perspectives on orchid conservation in Queen Sirikit Botanic Garden: recommendations based on a SWOT analysis. Thai Journal of Botany, 2 (special issue), 1-13.

Pedersen, H. Æ. (2013). Is it really worthwhile revising the same flora repeatedly? A case study in Thai Orchidaceae. Thai Forest Bulletin (Botany), 41, 145-156.

Pedersen, H. Æ., Kurzweil, H., Suddee, S. \& Cribb, P. J. (2011). Orchidaceae 1 (Cypripedioideae, Orchidoideae, Vanilloideae). In: T. Santisuk, \& K. Larsen (Eds.), Flora of Thailand 12(1) (pp. 1-302, Pls. I-XXIV). Bangkok: The Forest Herbarium, Department of National Parks, Wildlife and Plant Conservation.

Pedersen, H. Æ., Kurzweil, H., Suddee, S., de Vogel, E. F., Cribb, P. J., Chantanaorrapint, S., Watthana, S., Gale, S. W., Seelanan, T. \& Suwanphakdee, C. (2014). Orchidaceae 2 (Epidendroideae p.p.: Neottieae, Tropidieae, Nervilieae, Gastrodieae, Thaieae, Calypsoeae, Arethuseae, Collabieae, Cymbidieae). In: T. Santisuk, \& H. Balslev (Eds.), Flora of Thailand 12(2) (pp. 303-670, Pls. XXV-LVI). Bangkok: The Forest Herbarium, Department of National Parks, Wildlife and Plant Conservation.

Pedersen, H. Æ., Watthana, S. \& Srimuang, K. (2009). Gunnar Seidenfaden and his heritage: developments in the diversity and organization of Thai orchid studies. Thai Forest Bulletin (Botany), special issue, 156-168.

Pence, V. C. (2011). The possibilities and challenges of in vitro methods for plant conservation. Kew Bulletin, 65, $539-547$.

Phillips, R. D., Dixon, K. D. \& Peakall, R. (2012). Low population genetic differentiation in the Orchidaceae: implications for the diversification of the family. Molecular Ecology, 21, 5208-5220.

Pillon, Y., Fay, M. F., Shipunov, A. B. \& Chase, M. W. (2006). Species diversity versus phylogenetic diversity: a practical study in the taxonomically difficult genus Dactylorhiza (Orchidaceae). Biological Conservation, 129, 4-13.

Rae, D. (2011). Fit for purpose: the importance of quality standards in the cultivation and use of live plant collections for conservation. Biodiversity and Conservation, 20, 241-258.

Ramsay, M. M. \& Dixon, K. W. (2003). Propagation science, recovery and translocation of terrestrial orchids. In: K. W. Dixon, S. P. Kell, R. L. Barrett \& P. J. Cribb (Eds.), Orchid conservation (pp. 259-288). Kota Kinabalu: Natural History Publications (Borneo).

Rasmussen, F. N. (1982). The gynostemium of the neottioid orchids. Opera Botanica, 65, 1-96.

Rasmussen, F. N. (2010). Gunnar Seidenfaden's contributions to orchidology and conception of taxonomy. In: O. Seberg, G. Petersen, A. S. Barfod \& J. I. Davis (Eds.), Diversity, phylogeny and evolution in the monocotyledons (pp. 213-223). Aarhus: Aarhus University Press.

Santisuk, T., Chayamarit, K., Pooma, R. \& Suddee, S. (2006). Thailand red data: plants. Bangkok: Office of Natural Resources and Environmental Policy and Planning.

Sarasan, V. (2011). Importance of in vitro technology to future conservation programmes worldwide. Kew Bulletin, 65, 549-554.

Schuiteman, A. \& de Vogel, E. (1999). Orchids at the Leiden Hortus Botanicus. In: J. de Koning \& G. van Uffelen (Eds.), Hortus Botanicus Leiden. Catalogue part I 1998: Orchidaceae (pp. 10-14). Leiden: Universiteit Leiden. 
Seaton, P. T., Hu, H., Perner, H. \& Pritchard, H. W. (2010). Ex situ conservation of orchids in a warming world. Botanical Review, 76, 193-203.

Seaton, P. T. \& Pritchard, H. W. (2003). Orchid germplasm collection, storage and exchange. In: K. W. Dixon, S. P. Kell, R. L. Barrett \& P. J. Cribb (Eds.), Orchid conservation (pp. 227-258). Kota Kinabalu: Natural History Publications (Borneo).

Seberg, O. \& Petersen, G. (2009). How many loci does it take to DNA barcode a crocus? - PLoS One 4(2) (doi:10.1371/ journal.pone.0004598).

Seidenfaden, G. (1975-1980). Orchid genera in Thailand I-IX. Dansk Botanisk Arkiv, 29(2), 1-50; 29(3), 1-80; 29(4), 1-94; 31(1), 1-105; 31(3), 1-149; 32(2), 1-195; 33(1), 1-94; 33(3), 1-228 \& 12 pls.; 34(1), 1-104.

Seidenfaden, G. (1982-1988). Orchid genera in Thailand X-XIV. Opera Botanica, 62, 1-157; 72, 1-124; 83, 1-295; 89, $1-216 ; 95,1-398$.

Seidenfaden, G. \& Smitinand, T. (1959-1965). The orchids of Thailand: a preliminary list. Bangkok: The Siam Society.

Sterll, M. (2002). Botanischer Garten der Universität Kopenhagen, - ein 400-jähriger sehr lebendiger Greis. Orchidee (Hamburg), 53, 623-626.

Sterll, M. \& Rasmussen, F. N. (1988). Gunnar Seidenfaden and the Thai orchid collection in Copenhagen, Denmark. American Orchid Society Bulletin, 57, 1250-1254.

Stewart, J. (1992). The history of orchids at Kew. In: J. Stewart (Ed.), Orchids at Kew (pp. 11-24). London: HMSO.

Stewart, J. (1989). Orchid propagation by tissue culture techniques - past, present and future. In: H. W. Pritchard (Ed.), Modern methods in orchid conservation: the role of physiology, ecology and management (pp. 87-100). Cambridge: Cambridge University Press,.

Swarts, N. D. \& Dixon (2009). Perspectives on orchid conservation in botanic gardens. Trends in Plant Science, 14, 590598.

Tasker, S. (1989). The role of the living orchid collection at Kew in conservation. In: H. W. Pritchard (Ed.), Modern methods in orchid conservation: the role of physiology, ecology and management (pp. 159-162). Cambridge: Cambridge University Press.

Taylor, H. R. \& Harris, W. E. (2012). An emergent science on the brink of irrelevance: a review of the past 8 years of DNA barcoding. Molecular Ecology Resources, 12, 377-388.

Tetsana, N., Pedersen, H. Æ. \& Sridith, K. (2013). Five species of Liparis (Orchidaceae) newly recorded for Thailand. Thai Forest Bulletin (Botany), 41, 48-55.

Thammasiri, K. (2013). Ex situ conservation of Thai orchid species. In: J. Elliott, H. F. Kurzweil, P. O’Byrne, K. W. Tan, A. S. van der Schans, S. M. Wong \& T. W. Yam (Eds.), Proceedings of the 20th World Orchid Conference, Singapore, 2011 (pp. 141-148). Singapore: National Parks Board \& Orchid Society of South East Asia.

Tremblay, R. L., Ackerman, J. D., Zimmerman, J. K. \& Calvo, R. N. (2005). Variation in sexual reproduction in orchids and its evolutionary consequences: a spasmodic journey to diversification. Biological Journal of the Linnean Society, $84,1-54$.

Vane-Wright, R. I., Humphries, C. J. \& Williams, P. H. (1991). What to protect? - Systematics and the agony of choice. Biological Conservation, 55, 235-254.

Watthana, S. \& Pedersen, H. Æ. (2008). Phorophyte diversity, substrate requirements and fruit set in Dendrobium scabrilingue Lindl. (Asparagales: Orchidaceae): basic observations for re-introducton experiments. Natural History Journal of Chulalongkorn University, 8, 135-142.

Williams, F. N. (1904-1905). Liste des plantes connues du Siam. Bulletin de l'Herbier Boissier, sér. 2, 4, 217-232, 361-372, 1027-1034; 5, 17-32, 216-227, 428-439, 949-968.

Williams, S. J., Jones, J. P. G., Gibbons, J. M. \& Clubbe, C. (2015). Botanic gardens can positively influence visitors' environmental attitudes. Biodiversity and Conservation, 24: 1609-1620.

Winter, M., Devictor, V. \& Schweiger, O. (2012). Phylogenetic diversity and nature conservation: where are we? Trends in Ecology and Evolution, 28, 199-204.

Wyse Jackson, P. \& Sutherland, L. A. (2013). Role of botanic gardens. In: S. A. Levin (Ed.), Encyclopedia of biodiversity. 2nd ed., 6. Climate change and extinctions (pp. 504-521). Cambridge, Massachusetts: Academic Press.

Xiang, X.-G., Hu, H. \& Jin, X.-H. (2011). DNA barcoding of the recently evolved genus Holcoglossum (Orchidaceae: Aeridinae): a test of DNA barcode candidates. Molecular Ecology Resources, 11, 1012-1021. 